\title{
C $00-4356-2$
}

\section{ELECTROCHEMICAL INVESTIGATIONS OF NOVEL ELECTRODE MATERIALS}

Progress Report

for period 1 August 1978 - 31 July 1979

Wayne L. Worre11

Department of Materials Science and Engineering University of Pennsylvania

Philadelphia, Pennsylvania 19104

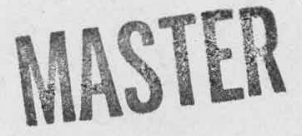

Apri1 1979

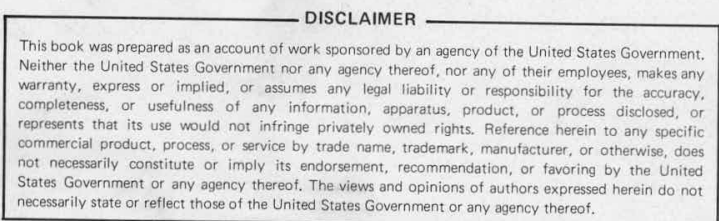

\section{Prepared for}

THE U. S. DEPARTMENT OF ENERGY

UNDER CONTRACT NO. EG-77-S-02-4356 


\section{DISCLAIMER}

This report was prepared as an account of work sponsored by an agency of the United States Government. Neither the United States Government nor any agency Thereof, nor any of their employees, makes any warranty, express or implied, or assumes any legal liability or responsibility for the accuracy, completeness, or usefulness of any information, apparatus, product, or process disclosed, or represents that its use would not infringe privately owned rights. Reference herein to any specific commercial product, process, or service by trade name, trademark, manufacturer, or otherwise does not necessarily constitute or imply its endorsement, recommendation, or favoring by the United States Government or any agency thereof. The views and opinions of authors expressed herein do not necessarily state or reflect those of the United States Government or any agency thereof. 


\section{DISCLAIMER}

Portions of this document may be illegible in electronic image products. Images are produced from the best available original document. 
Electrochemical Investigations of Nove1 Electrode Materials DOE Contract No. EG-77-S-02-4356

Progress Report for August 1, 1978 to July 31, 1979

Abstract

Electrochemical investigations of the compositional variation of the chemical potential and chemical diffusivity of lithium in $\mathrm{Li}_{x} \mathrm{TaS}_{2}$ and $\mathrm{Li}_{x} \mathrm{TiS}_{2}$ have been completed. The experimental results have been used to increase our understanding of the chemical bonding and transport mechanisms of lithium in the layered-structured intercalated disulfides. Our major emphasis during the current year has been to expand our earlier investigations of the co-intercalated disulfides: $\mathrm{Li}_{x} \mathrm{Na}_{0.18} \mathrm{TaS}_{2}$ and $\mathrm{Li}_{x} \mathrm{Na}_{0.18} \mathrm{TiS}_{2}$. Open-circuit voltage data clearly indicate that these co-intercalated compounds offer exciting possibilities as high-energy-density cathodes in lithium batteries. 
Lithium intercalated Group IV, V and VI transition metal disulfides have received considerable attention because of their potential applications as cathode materials in lithium batteries $(1-4)$. The chemical formulas of these intercalated compounds is $\mathrm{Li}_{\mathrm{X}} \mathrm{MS}_{2}$ where $\mathrm{M}$ is usually $\mathrm{Ti}, \mathrm{V}$, or $\mathrm{Ta}$ and $\mathrm{x}$ can vary from 0 to 1.0 . We have completed our electrochemical investigations of the compositional variation of the chemical potential and chemical diffusivity of 1 ithium in $\mathrm{Li}_{\mathrm{x}} \mathrm{TaS}_{2}$ and $\mathrm{Li}_{\mathrm{x}} \mathrm{TiS}_{2}$. The experimental results have increased our understanding of the chemical bonding and transport mechanisms of lithium in these layered-structured intercalated disulfides. However, our major emphasis during the past year has been to expand our earlier electrochemical investigations (5) of the co-intercalated disulfides: $\mathrm{Li}_{\mathrm{X}} \mathrm{Na}_{0.18}{ }^{\mathrm{TaS}_{2}}$ and $\mathrm{Li}_{x}{ }^{\mathrm{Na}} 0.18^{\mathrm{TiS}_{2}}$.

The variation of the open-circuit cell voltage with composition $x$ of the co-intercalated cathodes has been measured using cell (A) at $303^{\circ} \mathrm{K}$.

$$
\begin{array}{r}
\mathrm{Li}(\mathrm{s}) / \mathrm{Li}^{+}\left(\mathrm{LiClO}_{4} \text { in propylene carbonate) } / \mathrm{Li}_{x} \mathrm{Na}_{0.18} \mathrm{TaS}_{2}\right. \\
\text { or } \\
\mathrm{Li}_{x} \mathrm{Na}_{0.18}{ }^{\mathrm{TiS}_{2}}
\end{array}
$$

The $\mathrm{Na}_{0.18} \mathrm{TaS}_{2}$ cathodes in cell (a) were prepared using a sodium naphthalide solution in tetrahydrofurane to intercalate sodium into $\mathrm{TaS}_{2}$ particles, which had been previously annealed to obtain the stoichiometric $2 \mathrm{H}$ polytype structure of $\mathrm{TaS}_{2}$. A coulometric titration technique was used to intercalate sodium into $\mathrm{TiS}_{2}$ to prepare the $\mathrm{Na}_{0.18} \mathrm{TiS}_{2}$ cathodes. The sodium- 
intercalated powders were pressed to form the cathode pellets. Freshly cut lithium was used as the anodes in cell (A).

Preparation of the propylene carbonate electrolyte and the cell design were similar to that described elsewhere $(3,6)$.

A11 cel1 measurements were conducted inside a controlled atmosphere glove box at ambient temperature. The lithium composition $\mathrm{x}$ of the cathode was increased by discharging the cell at a constant current of $\sim 0.3 \mathrm{~mA} / \mathrm{cm}^{2}$ for a specific time period. After each discharge stage, the cell was held until the open circuit voltage was essentially constant $( \pm 0.001 \mathrm{~V}$ over 2-3 days). This discharge procedure was repeated to obtain data at other compositions. Cathode reversibility was established by reversing the current (charging the cel1). Within $0.02 \mathrm{~V}$ the same voltage value was obtained on charging as on discharging. X-ray diffraction patterns of the $\mathrm{Li}_{x} \mathrm{Na}_{0.18} \mathrm{TaS}_{2}$ and $\mathrm{Li}_{x} \mathrm{Na}_{0.18} \mathrm{TiS}_{2}$ cathodes used in cell (A) were obtained using a Debye-Scherrer camera with copper $k_{\alpha}$ radiation. The variation of the open-circuit voltage of cell (A) with the composition, $x$, of the $\mathrm{Li}_{x}{ }^{\mathrm{Na}} 0.18^{\mathrm{TaS}_{2}}$ and $\mathrm{Li}_{x} \mathrm{Na}_{0.18} \mathrm{TiS}_{2}$ cathodes is shown in Figs. (1) and (2), respectively. Data for the $\mathrm{Li}_{\mathrm{x}} \mathrm{TaS}_{2}{ }^{(6)}$ and $\mathrm{Li}_{\mathrm{x}} \mathrm{TiS}_{2}{ }^{(7,8)}$ cathode cells are also shown for comparison. Although the individual data points for the cointercalated cathodes are connected by a smooth curve in Figs. (1) and (2), more data are necessary to establish precisely the exact voltage-compositional relationships. However, the data shown in Figs. (1) and (2) clearly indicate that these cointercalated materials offer exciting possibilities as highenergy density cathodes in lithium batteries. 
$\underline{\text { References }}$

1. M. S. Whittingham, J. Electrochem. Soc. $123, p .315$ (1976).

2. D. W. Murphy, J. N. Carides, F. J. DiSalvo, C. Cros and J. V. Waszczak, Mat. Res. Bu11., 12, p. 825 (1977).

3. S. Basu and W. L. Worre11, Electrode Materials and Processes for Energy Conversion and Storage, Electrochem. Soc., Princeton, N. J., 1977, p. 861.

4. M. S. Whittingham, Chemistry of Intercalation Compounds: Metal Guests in Chalcogenide Hosts, Prog. in Solid State Chem. 12, p. 41 (1978).

5. S. Basu and W. L. Worre11, Patents pending.

6. S. Basu and W. L. Worre11, submitted to J. Electrochem. Soc.

7. S. Basu and W. L. Worrell, submitted to J. Electrochem. Soc.

8. M. S. Whittingham, Science, 192, p. 1126 (1976). 


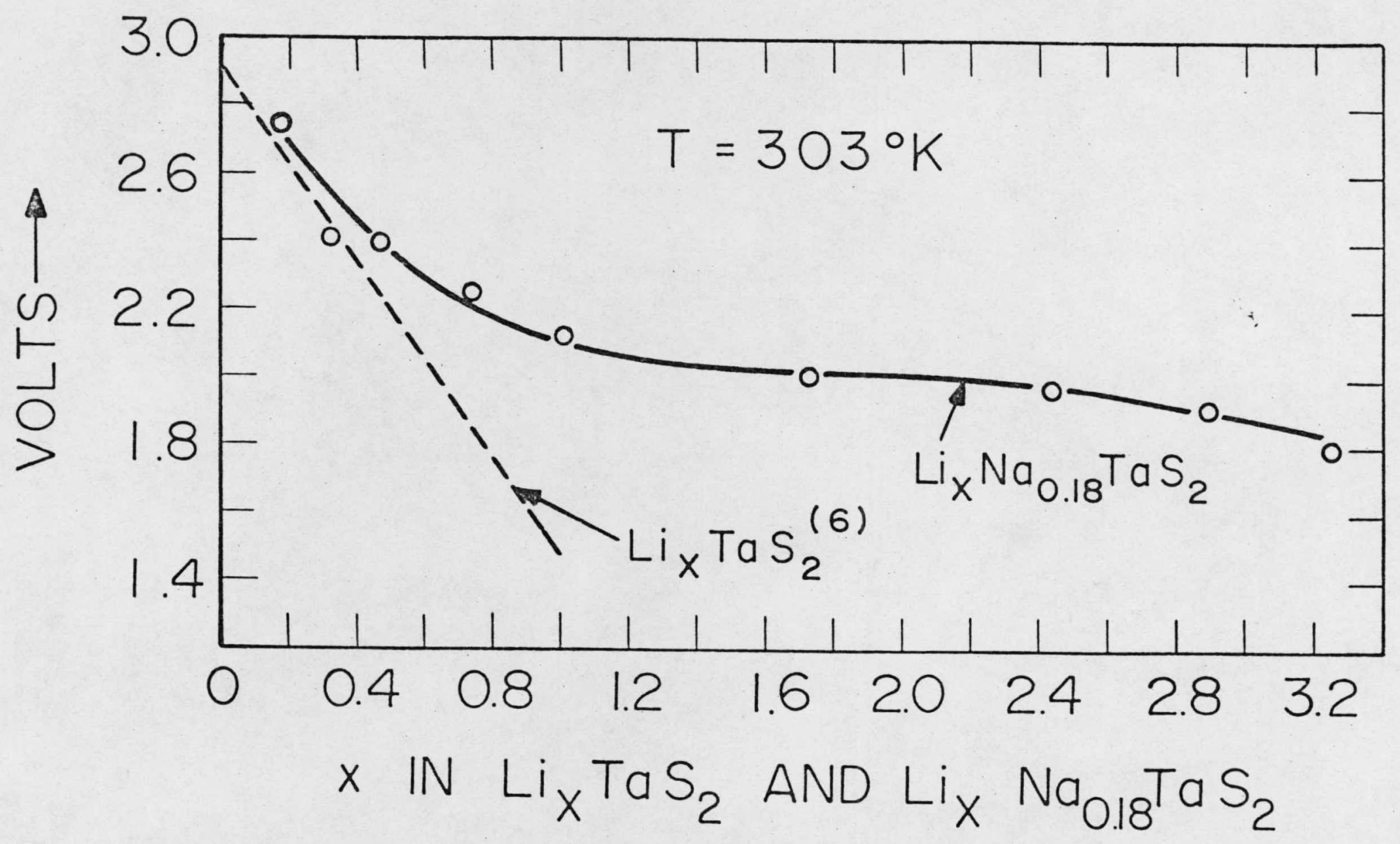

Fig. 1. Variation of the open-circuit voltage of cell (A) With composition, $\mathrm{x}$, of the $\mathrm{Li}_{x} \mathrm{TaS}_{2}$ and
$\mathrm{Li}_{\mathrm{x}} \mathrm{Na} 0.1 \mathrm{STS}_{2}$ cathodes. 


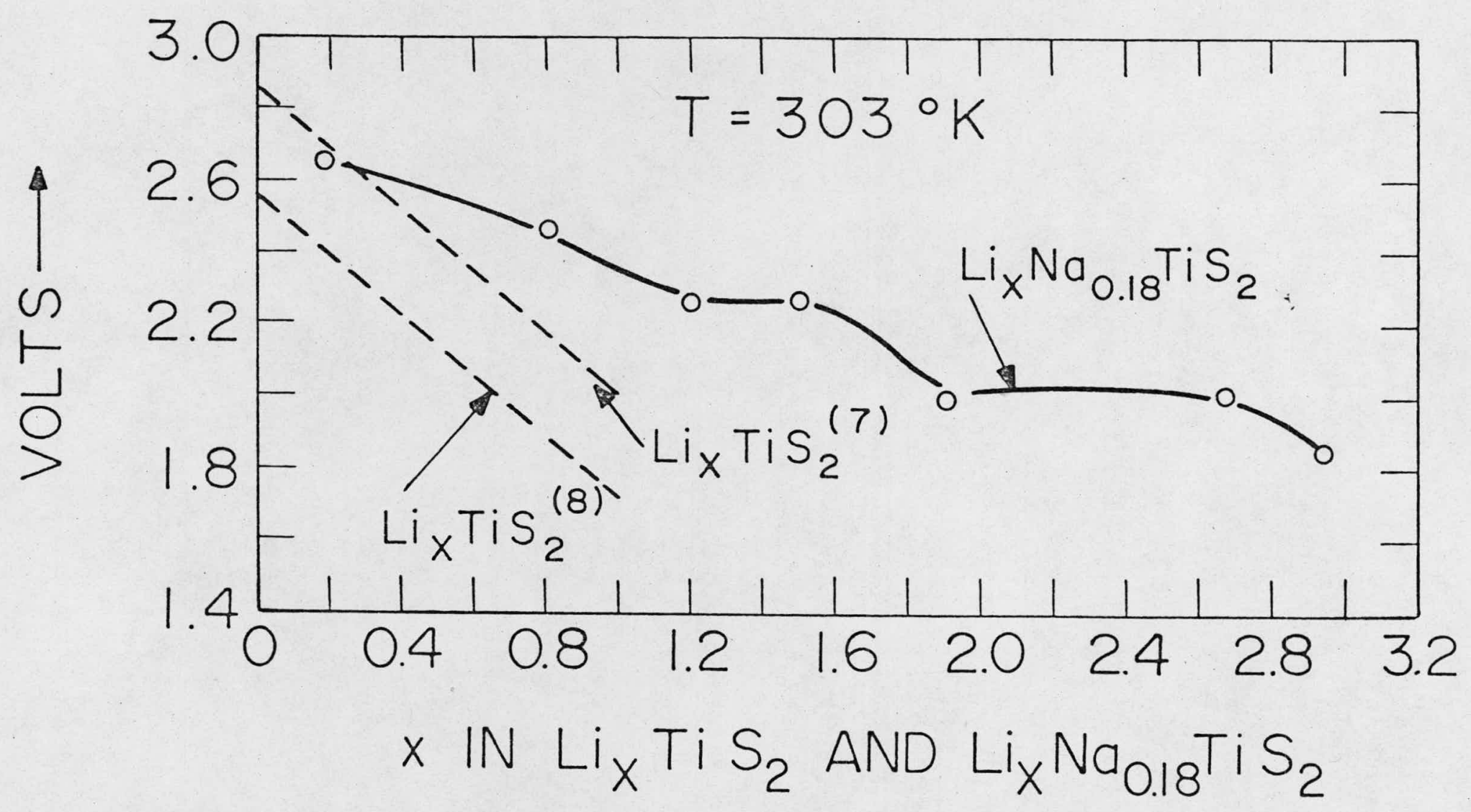

Fig. 2. Variation of the open-circuit voltage of cell (A) with composition, $x$, of the $\mathrm{Li}_{\mathrm{x}} \mathrm{TiS}_{2}$ and

$\mathrm{Li}_{x} \mathrm{Na}_{0.18^{\mathrm{TiS}}}$ cathodes. 